\title{
HUBUNGAN KARAKTERISTIK INDIVIDU DAN PRAKTIK KESEHATAN KELUARGA DENGAN KEJADIAN PRE-HIPERTENSI DI KELURAHAN SRENGSENG SAWAH KECAMATAN JAGAKARSA JAKARTA SELATAN
}

\author{
Dini Tryastuti \\ Politeknik Karya Husada \\ E-mail : tryastutidini@yahoo.com
}

\begin{abstract}
Abstrak
Pre-hipertensi adalah suatu kondisi dimana nilai tekanan darah sistolik 120-139 mmHg dan nilai tekanan darah diastolik $80-89 \mathrm{mmHg}$, diperkenalkan tidak sebagai katagorisasi penyakit tetapi untuk mengidentifikasi individu yang sangat berisiko hipertensi dan penyakit kardiovaskular. Praktik kesehatan keluarga adalah upaya yang dilakukan keluarga untuk memelihara dan meningkatkan status kesehatan keluarga, khususnya dalam pencegahan prehipertensi. Penelitian ini bertujuan untuk mengetahui hubungan antara karakteristik individu dan praktik kesehatan keluarga dengan kejadian prehipertensi pada usia dewasa. Desain penelitian ini adalah deskriptif observasional dengan pendekatan cross-sectional. Jumlah sampel penelitian sebanyak 107 orang yang diambil melalui teknik cluster sampling. Hasil penelitian menunjukkan bahwa ada hubungan antara karakteristik individu dan praktik kesehatan keluarga dengan kejadian pre-hipertensi. Faktor yang paling dominan mempengaruhi prehipertensi adalah Indeks massa tubuh $(\mathrm{OR}=29,4)$ Hasil ini merekomendasikan perawat untuk memberikan pendidikan kesehatan kepada seluruh penderita prehipertensi untuk melakukan perubahan gaya hidup agar tidak menderita hipertensi dan penyakit kardiovaskuler dimasa akan datang.
\end{abstract}

Kata Kunci: Karakteristik Individu, Praktik Kesehatan Keluarga, Pre-hipertensi

\section{Abstract}

Prehypertension is a state where blood pressure sistolic 120-139 mmHg and diastolic 80$89 \mathrm{mmHG}$. It is not a catagorical of disease but for indicating individual that has higher risk of hypertension and cardiovasculer diseases. Family health practices are effort that was done by family to maintain and promote family health. Especially in the prevention of prehypertension. The research aims to determinan assosiation of individual characteristics and family health practices with prehypertension at aged adults. The research design used observational descriptive design with cross sectional approach. Total sample of 107 people were taken by using a cluster sampling technique. The results showed that there are correlations between individual characteristics and family health practices toward prehypertension, the result also showed that body mass index $(O R=29,4)$ was the highest factor that impact prehypertension case. The result recommended nurses to give health education to all of prehypertension adults to change life style to prevent hypertension and cardiovasculer diseases in the future

Keywords: Individual Characteristics, family Health Practices, prehypertension 


\section{PENDAHULUAN}

Penyakit hipertensi dan penyakit kardiovaskuler harus segera dicegah sejak awal mengingat efek jangka panjang yang diakibatkannya,seperti aspek mortalitas maupun pengeluaran anggara dana yang tinggi, upaya tersebut dilakukan oleh JNC 7 (The Seventh Report of The Joint National Committe on prevention, detection, evaluation and treatment of high blood pressure) dengan menambahkan klasifikasi baru tekanan darah yaitu prehipertensi (Hernandez \& Anderson, 2012).

Pre-hipertensi merupakan kondisi tekanan darah sistolik ; 120 $139 \mathrm{mmHg}$ atau tekanan darah diastolic ; 80 - 89 mmHg (Kim, 2011). Chiang (2013) menambahkan pre-hipertensi adalah tahapan terlebih dahulu sebelum terjadinya hipertensi serta tidak disertai dengan gejala langsung yang dirasakan oleh individu penderita namun berisiko tinggi menjadi hipertensi dan penyakit kardiovaskuler dibandingkan tekanan darah normal. Kasus pre-hipertensi secara global pada penduduk dewasaadalah 36\% (Guo, et al., 2011). Liu dan Goodman (2012) menyatakan di Amerika Serikat diperkirakan setengah dari penduduk dewasa mengalami pre- hipertensi. Kondisi ini didukung oleh penelitian yang dilakukan Pantea (2011) bahwa di Amerika serikat jumlah penderita pre-hipertensi di estimasi sebanyak 32 juta pria dan 21 juta wanita yang berusia 20 tahun atau lebih. Pada negara di wilayah Asia juga cendrung tinggi, prevalensi prehipertensi di negara India adalah $30,1 \%$ dan di China mencapai
47\% (AHA, 2013). Keadaan serupa juga ditemui di negara di Wilayah Asia lainnya, prevalensi pre-hipertensi usia dewasa di Indonesia juga tinggi, bahkan melebihi kedua negara tersebut yaitu 48,4\% (Churniawati, 2015).

Perkembangan pre-hipertensi menjadi hipertensi serta komplikasinya merupakan tantangan dalam permasalahan kesehatan masyarakat di seluruh dunia. Karena kasus pre- hipertensi berhubungan langsung dengan kejadian hipertensi dimasa akan datang. Empat dari lima individu prehipertensi dewasa diperkirakan akan berkembang menjadi hipertensi 10 tahun kemudian (Funchs. 2011). Perubahan gaya hidup yang direkomendasikan untuk pencegahan pre-hipertensi serta penurunan tekanan darah bagi penderita prehipertensi adalah menurunkan dan mempertahankan berat badan normal, DASH (DietaryApproach Stop Hipertension) dan peningkatan aktifitas fisik (Muruganathan, 2012).

$$
\text { Upaya pencegahan pre- }
$$
hipertensi juga dijelaskan NHLBI atau The National Hearth, Lung, Blood Institute yaitu penurunan berat badan $18,5-24,9 \mathrm{Kg} / \mathrm{m} 2$, menerapkan DASH (Dietary Approach Stop Hipertension) dengan cara gaya hidup lebih banyak mengkonsumsi banyak buah dan sayur, rendah lemak, konsumsi rendah garam, aktifitas fisik sedang 30 menit setiap hari, tidak merokok, mengurangi mengkonsumsi alkohol dan mengurangi stress (Hernandes \& Anderson, 2012; Kemenkes, 2015). Gaya hidup individu sangat di pengaruhi oleh keluarga, hal ini dikarenakan keluarga merupakan 
wadah primer tempat terbentuknya pola perilaku individu (Ali, 2010). Hal ini sejalan dengan Friedman, Bowden \& Jones (2003), Kaakinen (2014) \& Notoadmodjo (2014) yang menyatakan bahwa keluarga adalah sistem dasar dimana praktik kesehatan dan pemeliharaan kesehatan dilakukan, selain itu anggota keluarga merupakan role model dasar bagi anggota keluarga lainnya dalam melakukan praktik kesehatan. Allender dan Warner (2014) menambahkan bahwa praktik hidup sehat seseorang seperti praktik diet sehat, praktik aktifitas fisik dan merokok sangat dipengaruhi oleh keluarga karena keluarga merupakan tempat terbentuk dan berkembangnya nilai-nilai kesehatan, perilaku kesehatan dan persepsi risiko kesehatan.

Menurut Friedman. Bowden dan Jones (2003) praktik kesehatan keluarga yang mempengaruhi risiko peningkatan tekanan darah dan penyakit kardiovaskuler pada masa akan datang adalah pola makan, pola aktivitas fisik, praktik merokok dalam keluarga. Hal ini sejalan dengan Stanhope dan Lancaster (2014) bahwa praktik diet, aktifitas fisik dan merokok dalam keluarga perlu dikaji secara kompeherensif, karena turut menjadi indikator risiko masalah kardiovaskuler pada anggota keluarga. Kemenkes (2015).

\section{METODE PENELITIAN}

Desain penelitian ini adalah deskriptif observasional dengan pendekatan cross sectional, dengan total sampel 107 dewasa. Variabel yang diukur pada penelitian ini adalah karakteristik individu dan praktik kesehatan keluarga menggunakan kuesioner pengembangan dari Friedman. Bowden dan Jones (2003) untuk variabel praktik kesehatan keluarga.

Analisis dilakukan secara univariat serta bivariat. Analisis univariat bertujuan untuk menggambarkan karakteristik responden yang meliputi usia, jenis kelamin, riwayat keluarga hipertensi, IMT dan praktik kesehatan keluarga. Analisis bivariat bertujuan untuk melihat hubungan antara karakteristik individu dan praktik kesehatan keluarga dengan kejadian prehipertensi.

\section{HASIL PENELITIAN}

Responden pada penelitian yang dilakukan sebagian besar berusia dewasa pertengahan $(51,4 \%)$, jenis kelamin laki-laki (52,3\%), memiliki riwayat keluarga hipertensi sebesar (57\%), dan lebih dari setengah jumlah responden memiliki IMT normal $(65,4 \%)$. Sedangkan pada variabel praktik kesehatan keluarga sebagian besar diet keluarga kurang baik $(53,3)$, aktivitas fisik keluarga kurang baik $(57,9)$ dan praktik merokok keluarga negative $(52,6)$.

Analisis

bivariat Menghasilkan ada hubungan antara usia individu dewasa dengan kejadian prehipertensi $(p=0,015 ; \alpha$ $=0,05$ ). pada usia dewasa diketahui bahwa individu dewasa pertengahan mempunyai peluang 2,81 kali untuk mengalami prehipertensi dibandingkan individu usia dewasa awal $(\mathrm{OR}=2,81 ; 95 \%$ CI 1,3-6,1).

Analisis lebih lanjut menghasilkan tidak ada hubungan antara jenis kelamin dengan kejadian 
prehipertensi pada usia dewasa ( $\mathrm{p}$ $=0,926 ; \alpha=0,05)$ diketahui bahwa individu dewasa yang berjenis kelamin perempuan mempunyai peluang 1,17 kali untuk mengalami prehipertensi dibandingkan individu usia dewasa berjenis kelamin laki-laki $\quad(\mathrm{OR}=1,117$; $95 \% \mathrm{CI}$ 0,5.- 2,4). Analisis juga menunjukkan ada hubungan antara riwayat keluarga hipertensi dengan kejadian prehipertensi pada usia dewasa $(p=0,026 ; \alpha=0,05)$. Individu dewasa yang memiliki riwayat keluarga hipertensi mempunyai peluang 2,63 kali untuk dapat mengalami prehipertensi dibandingkan individu usia dewasa yang tidak memiliki riwayat keluarga hipertensi $(\mathrm{OR}=2,63$; $95 \%$ CI 1,2$5,8)$.

Analisis lebih lanjut juga menunjukkan ada hubungan antara IMT dengan kejadian prehipertensi pada usia dewasa $(\mathrm{p}=0,000 ; \alpha=$ $0,05)$. Individu dewasa dengan IMT tidak normal mempunyai peluang 14,93 kali untuk mengalami prehipertensi dibandingkan individu usia dewasa dengan IMT normal $(\mathrm{OR}=14,93 ; 95 \%$ CI 5,1.- 43,6).

Ada hubungan antara diet keluarga dengan kejadian prehipertensi pada usia dewasa $(\mathrm{p}=$ $0,000 ; \alpha=0,05)$. Individu dewasa dengan keluarga yang melakukakan diet kurang baik mempunyai peluang 5,57 kali untuk mengalami prehipertensi dibandingkan individu usia dewasa dengan keluarga yang melakukan diet keluarga yang baik $(\mathrm{OR}=5,37 ; 95 \%$ CI 2,308-12,493).

Analisis lebih lanjut juga memperlihatkan ada hubungan antara aktifitas fisik keluarga dengan kejadian prehipertensi pada usia dewasa $(p=0,000 ; \alpha=0,05)$.
Individu dewasa dengan keluarga yang melakukakan aktifitas fisik kurang baik mempunyai peluang 5,37 kali untuk mengalami prehipertensi dibandingkan individu usia dewasa dengan keluarga yang melakukan aktivitas fisik yang baik (OR $=5,37 . ; 95 \%$ CI 2,308.- 12,493).

Analisis lebih lanjut juga memperlihatkan ada hubungan antara praktik merokok keluarga dengan kejadian prehipertensi pada usia dewasa $(p=0,034 ; \alpha=0,05)$. Individu dewasa dengan keluarga yang melakukakan kebiasaan merokok kurang baik mempunyai peluang 2,59 kali untuk mengalami prehipertensi dibandingkan individu usia dewasa dengan keluarga yang melakukan kebiasaan merokok baik $(\mathrm{OR}=2,59 ; 95 \%$ CI 1,150-5,821).

\section{PEMBAHASAN}

Berdasarkan analisis secara univariat menunjukkan bahwa proporsi individu usia dewasa yang mengalami prehipertensi hampir sama dengan yang tidak mengalami prehipertensi dengan selisih $(0,5 \%)$. Perbedaan angka kejadian yang kecil ini menunjukkan bahwa kejadian prehipertensi terjadi hampir setengah pada usia dewasa di Kelurahan Srengseng Sawah. Dari analisis data ditemukan proporsi prehipertensi pada usia dewasa $(49,5 \%)$ melebihi angka penelitian sebelumnya. Penelitian yang telah dilakukan oleh Guo, et al., (2011) menunjukkan ada $36 \%$ Kasus pre- hipertensi secara global. Pada negara di wilayah Asia sendiri, prevalensi pre- hipertensi di negara India adalah $30,1 \%$ dan di China mencapai 47\% (AHA, 2013). Begitu juga penelitian yang dilakukan oleh Churniawati (2015) 
kasus prehipertensi di indonesia sebanyak $48,4 \%$.

\section{Hubungan usia dengan kejadian prehipertensi}

Berdasarkan hasil analisis bivariat terdapat hubungan antara kelompok usia dewasa dengan kejadian prehipertensi. Diperoleh proporsi prehipertensi pada dewasa pertengahan lebih besar dari dewasa awal. Serupa dengan penelitian yang dilakukan oleh Yadaf (2008), Gusman (2013, Yang et al (2015) dan Jang et al (2015) dari analisis data ditemukan bahwa salah satu faktor penyebab pre-hipertensi adala peningkatan usia.

\section{Hubungan jenis kelamin dengan kejadian prehipertensi}

Berdasarkan analisis bivariat didapatkan tidak ada hubungan antara jenis kelamin terhadap prehipertensi. Hal ini serupa dengan penelitian yang dilakukan oleh Maqbali et al (2013) yaitu menganalisis faktor determinan prehipertensi, penelitian ini dilakukan terhadap 1498 responden dewasa di Oman dengan metode penelitian crossecsional, dari hasil analisis data diperoleh tidak ada hubungan jenis kelamin terhadap prehipertensi dengan $\mathrm{p}$ value 0,16 . Keadaan ini juga didukung oleh hasil penelitian dilakukan oleh Yang et al (2015) terhadap 9488 dewasa di Cina Utara dengan metode penelitian crossectional dari analisis bivariat ditemukan nilai $\mathrm{p}$ value 0,229 yang memiliki arti tidak ada hubungan antara jenis kelamin dengan preipertensi.

\section{Hubungan riwayat keluarga hipertensi dengan kejadian prehipertensi}

Berdasarkan analisis bivariat diperoleh hubungan antara riwayat keluarga hipertensi dengan kejadian prehipertensi. Senada dengan penelitian yang dilakukan oleh Koura et al (2012) yaitu menganalisis faktor- faktor yang mempengaruhi prehipertensi yang dilakukan terhadap responden 1300 dewasa di Dammam, Saudi Arabia dengan metode penelitian crosssecsional, hasil penelitian ini memperlihatkan bahwa faktor risiko kejadian prehipertensi salah satunya adalah riwayat keluarga hipertertensi. Hasil ini senada juga dengan penelitian yang telah dilakukan oleh Ravi, Ashok dan Renuka (2015) terhadap 402 responden dewasa di India, dengan metode cross-sectional, dari analisis data ditemukan bahwa diperoleh hubungan individu yang memiliki riwayat hipertensi dengan kejadian prehipertensi.

\section{Hubungan IMT dengan kejadian prehipertensi}

Berdasarkan hasil analisis bivariat ditemukan hubungan IMT dengan kejadian prehipertensi. Hal ini sejalan dengan penelitian yang dilakukan oleh Koura et al (2012; Yang et al (2015); Aghababaei et al (2012) dan Ding et al (2015) dengan melakukan metode penelitian crosssectional, dari analisis data diperoleh bahwa terdapat hubungan antara IMT dengan kejadian prehipertensi.

$\begin{array}{lr}\text { Hubungan diet } & \text { keluarga } \\ \text { dengan kejadian prehipertensi }\end{array}$


dewasa. Diet keluarga adalah pengolahan dan penyajian makanan untuk semua anggota keluarga, keadaan ini secara tidak langsung akan berpengaruh terhadap kondisi fisiologis seluruh anggota keluarga seperti peningkatan kadar lemak tubuh dan kadar sodium dalam tubuh sehingga dapat meningkatkan risiko penyakit kardiovaskluler (Friedman, Bowden \& Jones, 2010). Hal ini senada dengan penelitian yang dilakukan oleh Yang et al (2015) hiperkolesteolemia dan hipertrigliserida berhubungan dengan kejadian prehipertensi, hal lain diperoleh dari penelitian yang dilakukan oleh Khanam et al (2015) dari analisis data ditemukan konsumsi buah-buahan dan sayursayuran yang kurang berhubungan dengan kejadian prehipertensi. Hal lain juga ditemukan dari hasil penelitian yang Moinuddin, Gupta \& Saxena (2016) yang menghasilkan bahwa intake garam juga berhubungan dengan kejadian prehipertensi.

\section{Hubungan aktivitas fisik keluarga dengan kejadian prehipertensi}

Hasil analisis bivariat menghasilkan adanya hubungan antara aktivitas fisik keluarga dengan kejadian prehipertensi pada dewasa, hasil ini senada dengan penelitian yang dilakukan oleh Do et al (2014) yang menganalisis faktorfaktor yang mempengaruhi prehipertensi yang dilakukan terhadapn 17.199 responden dewasa di vietnam dengan metode penelitian crossectional, hasil penelitian ini menemukan bahwa faktor risiko yang berhubungan dengan kejadian prehipertensi salah satunya adalah kurangnya aktivitas fisik. Hal ini Senada dengan penelitian yang dilakukan oleh Khanam et al (2015) terhadap 350 responden dewasa di Babgladesh juga ditemukan hubungan aktivitas fisik terhadap kejadian prehipertensi.

\section{Hubungan praktik merokok keluarga dengan kejadian prehipertensi}

Analisis bivariat juga menghasilkan adanya hubungan antara praktik merokok keluarga dengan kejadian prehipertensi pada dewasa, hal ini senada dengan penelitian yang dilakukan oleh Khanam et al (2015) yang menganalisis faktor-faktor yang menyebabkan prehipertensi, dari analisis data ditemukan bahwa terdapat hubungan antara merokok dengan kejadian prehipertensi, hal ini juga senada dengan hasil penelitian yang dilakukan oleh Do et al (2014) bahwa ditemukan adanya hubungan antara merokok dengan kejadian prehipertensi. Hal lain yang ditemukan pada penelitian yang dilakukan oleh Shiue (2014), dari analisis data diperoleh terdapat hubungan individu yang terpapar asap rokok secara terus menerus dengan akan meningkatkan kasus aterosklerosis yang dapat meningkatkan kejadian prehipertensi.

\section{SIMPULAN DAN SARAN}

\section{Simpulan}

1. Karakterisitik individu dewasa: sebahagian besar responden berusia dewasa pertengahan $(51,4 \%)$, jenis kelamin laki-laki $(52,3 \%)$, tidak memiliki riwayat keluarga hipertensi sebesar (67 $\%)$, dan lebih dari setengah jumlah responden memiliki IMT normal $(65,4 \%)$. 
2. Praktik kesehatan keluarga pada individu dewasa adalah sebagian besar $\quad(53,3 \%)$ responden memiliki diet keluarga yang kurang baik, aktifitas fisik dalam keluarga responden adalah kurang baik (57,9\%), dan praktik merokok keluarga negatif sebesar $(52,6 \%)$.

3. Kejadian prehipertensi pada penduduk dewasa di Kelurahan Srengseng Sawah Kecamatan Jagakarsa Jakarta Selatan cukup tinggi yaitu hampir mencapai setengah responden $(49,5 \%)$.

4. Terdapat hubungan antara karakteristik individu (usia, riwayat keluarga hipertensi dan IMT) dengan kejadian prehipertensi pada individu dewasa di Kelurahan Srengseng Sawah Kecamatan Jagakarsa Jakarta Selatan.

5. Terdapat hubungan antara praktik kesehatan keluarga (diet keluarga, aktifitas fisik keluarga, praktik merokok dalam keluarga) dengan kejadian prehipertensi pada individu dewasa di Kelurahan Srengseng Sawah Kecamatan Jagakarsa Jakarta Selatan.

6. Faktor yang paling dominan mempengaruhi kejadian prehipertensi pada individu dewasa di Kelurahan

Srengseng Sawah Kecamatan Jagakarsa Jakarta Selatan Adalah indeks massa tubuh dewasa dengan OR (29.431).

\section{Saran}

1. Petugas kesehatan sebaiknya meningkatkan promosi kesehatan terkait prehipertensi melalui metode yang inovatif seperti pemasanagan iklan di TV dan radio, Pemasangan reklame mengenai pre-hipertensu, talkshow, demonstrasi langsung yang lengkap dengan alat peraganay, focus group discussion: dan pembentukan kelompok pendukung khusus untuk prehipertensi; kemitraan dengan menjalin kerjasama dengan posbindu PTM, kelurahan, puskesmas dan dinas kesehatan dalam menskrening prehipertensi secara berkala.

2. Dalam kurikulum pendidikan keperawatan, harus mengembangkan pembahasan mengenai prehipertensi sehingga mahasiswa mengetahui pengetahuan yang baik dalam memberikan pelayanan keperawatan terkait prehipertensi.

3. Penelitian dengan metode yang berbeda harus dilakukan untuk peneliti selanjutnya, misalnya kuasi eksperimen mengenai pengaruh pengaruh kelompok pendukung (Support group) terhadap praktik kesehatan individu maupun praktik kesehatn keluarga terkait hidup sehat untuk mencegah prehipertensi dan pengaruh pendidikan kesehatan menggunakan audiovisual terhadap peningkatan praktik kesehatan individu maupun praktik kesehatan keluarga pada penderita prehipertensi, dan lain-lain.

4. Pada kader kesehatan khususnya kader PTM harus diberikan penyegaran ataupun pelatihan kader tentang prehipertensi dan hal-hal yang menyebabkan prehipertensi seperti karakteristik, koping individu dan praktik kesehetan individu maupun praktik 
Kesehatan keluarga sehingga mereka dapat menjadi perpanjangan tangan dari perawat komunitas dalam melakukan promosi kesehatan pada keluarga dan masyarakat secara menyeluruh.

\section{DAFTAR PUSTAKA}

Ali, S. (2010). Psikologi Keluarga; Jakarta.Bumi Mahadika.

Allender, J. A., Rector,C., Warner, K.D. (2014). Community Health Nursing; Promoting The Public's Health 8th Eddition. Philadelphia: Lippincott Williams \& Wilkins.

Al-Maqbali, A. A., Temple-Smith, M., Ferler, J., \& Blackberry, I. (2013). Prevalence and determinants of prehypertension among omani adults attending noncommunicable disease screening program in primary care setting in Sohar city. Oman Medical Journal,28(5), 316-323.

Chiang, et al. (2013). CardioMetabolic Risk Factors and prehypertension in pearsons without diabetes, hypertension and cardiovascular disease. $B M C$ Public Health. 13. 370.

Ding, Y., Gu, D., Zhang, Y., Han, W., Liu, H., \& Qu, Q. (2015). Significantly increased visceral adiposity index inprehypertension. PLoS ONE, 10(4),1-12.

Edelman \& Mandle (2010). Health Promotion Throughout The Life Span. Seventh Edition. St. Louis: Mosby Elsevier.
Friedman, Bowden \& Jones, (2003).Family Nursing: Research, Theory, and Practice. Fifth Edition. New Jersey: Prentice Hall.

Guo, X.., Zou L., Zhang, X \& Zheng L. (2011). Prehypertension. Texas heart institute journal. 38 (6). 643-652.

Jang, E., Baek, Y., Kim, Y., Park, K., \& Lee, S. (2015). Sasang constitution may act as a risk factor for prehypertension. BMC Complementary and Alternative Medicine, 15(1), 231.

Kaakinen, Coehlo, Steele, Tabacco \& Hanson (2015). Family Health Care Nursing. Fifth Edition. Philadelphia: F.A. Davis Company.

Kemenkes RI. (2015). Waspadai Hipertensi; Kendalikan Tekanan Darah. Jakarta: Kemenkes RI.

Khanam, M. A., Lindeboom, W., Razzaque, A., Niessen, L., \& Milton, A. H. (2015). Prevalence and determinants of pre-hypertension and hypertension among the adults in rural Bangladesh: findings from a communitybased study. BMC Public Health, 15, 203.

Kim, S. H., et al. (2011). Early abnormalities of cardiovascular structure and function in middle age korean adult with prehypertension: the korean genome epidemiology study. American Journal of Hypertension. 24 (2). 218224. 
Kozier. B, Erb. G, Berman. A, \& Synder.S.J. (2011). Buku Ajar Fundamental Keperawatan: Konsep, Proses, \& Praktik. Jakarta: ECG.

Liu et al. (2012). Blood Pressure Responses to Acute \& Choronic Excercise are Related in Prehypertension. The American College of Sports Medicine. 12. 16441652

Notoatmodjo, S. (2014). Ilmu Perilaku Kesehatan. Jakarta: Rineka Cipta.

Prabowo, L. (2008). Faktor-faktor yang berhubungan dengan hipertensi. Universitas Sumatra Utara.

Ravi, M. R., Ashok, N. C., \& Renuka, M. (2015). Prevalence of prehypertension in a rural district of Southern India. International Journal of Preventive Medicine, 2015- September.

Sunaryo. (2010). Psikologi Untuk Keperawatan; Jakarta. EGC.

Yang, G., Ma, Y., Wang, S., Su, Y., Rao, W., Fu, Y., ... Kou, C. (2015). Prevalence and correlates of prehypertension and hypertension among adults in northeastern China: A cross-sectional study. International Journal of Environmental Research and Public Health, 13(1), 1-13. 